\title{
Komplex nyaki és agyi érpatológia endovascularis kezelése
}

\author{
Oláh Csaba dr. ${ }^{1,2}$ - Czabajszki Máté dr. ${ }^{1}$ - Lázár István dr. ${ }^{1}$ \\ ${ }^{1}$ Borsod-Abaúj-Zemplén Megyei Kórház és Egyetemi Oktató Kórház, Miskolc \\ ${ }^{2}$ Debreceni Egyetem, Klinikai Tudományok
}

\begin{abstract}
A szerzők bemutatják egy nőbeteg komplex, többlépcsős intervenciós neuroradiológiai ellátását, amelynek során azonos oldali intraduralisan terjedő, inoperábilis glomus jugulare tumor, arteria carotis interna szúkület és arteria cerebri media aneurysma kezelését végezték. Az irodalomban esetismertetésük az első közlemény, amelyben a három betegség együtt, azonos oldalon fordul elő és amelyet többlépcsősen, endovascularisan kezeltek. A kezelési lépések mellett bemutatásra kerül a glomus jugulare tumor tünettana, stádiumbeosztása, kezelési lehetőségei, illetve az arteria carotis interna szúkület és intracranialis agyi érzsákok kezelési irányelvei. Orv Hetil. 2017; 158(18): 706-710.
\end{abstract}

Kulcsszavak: glomustumor, agyi aneurysma, embolisatio, coilozás, carotisszúkület, stentelés

\section{Endovascular treatment of complex vascular pathology in neck and brain region}

\section{Case report}

Authors present complex multistage endovascular treatment of female patient with an intradural infiltrative, inoperable tumor of the glomus jugulare, a stenosis of the internal carotid artery and an aneurysm of middle cerebri artery. In the literature our case report is the first announcement in which three pathology coexist ipsilateral in one patient and the patient has been treated step by step by endovascular procedures. Beside the endovascular treatment steps they display glomus jugulare tumor's symptoms, staging, treatment options and also the current treatment guidelines of internal carotid artery stenosis and intracranial aneurysms.

Keywords: glomus tumor, intradural aneurysm, embolisation, coiling, carotid stenosis, stenting

Oláh Cs, Czabajszki M, Lázár I [Endovascular treatment of complex vascular pathology in neck and brain region]. Orv Hetil. 2017; 158(18): 706-710.

(Beérkezett: 2017. január 31.; elfogadva: 2017. február 27.)

\section{Rövidítések}

ACI $=$ arteria carotis interna; $\mathrm{ACM}=$ arteria cerebri media; CAS = carotis-angioplastica és stentelés; CEA = carotisendarterectomia; $\mathrm{CT}=$ komputertomográfia; $\mathrm{MEN}=$ multiplex endokrin neoplasia; $\mathrm{MR}=$ mágneses rezonancia $;$ PVA = polivinilalkohol

A 60 éves nőbeteg bal oldali pulzáló tinnitust, hypacusist panaszolt, majd időnként szédülés és járásbizonytalanság jelentkezett nála. Ezt követően néhány hónap alatt bal oldali anacusis, bal oldali IX., X., XI. és XII. agyidegbénulás alakult ki (rekedt lett, nyelése jelzetten nehezítetté, bal vállmozgásai korlátozottá váltak, kiöltött nyelvcsúcsa balra deviált). A beteg vérnyomása alacsony volt, de néha hirtelen kiugrott. Kivizsgálás során a bal oldali arteria ca- rotis interna (ACI) kezdeti szakaszán 80\%-os szúkület, a bal arteria cerebri media (ACM) bifurcatióban egy széles nyakú aneurysma, valamint egy bal oldali glomus jugulare tumor igazolódott. Első lépésként a szignifikáns bal ACI-szúkület stentelését végeztük (1. ábra), majd az ápolási határnap elteltével a bal ACM-aneurysmát ballonos védelemben coiloztuk (2. és 3. ábra). A glomus jugulare tumor Fisch-beosztás szerint a $\mathrm{D}_{\mathrm{el}}$ kategóriába került besorolásra intracranialis növekedése miatt (4-7. ábra). Ez alapján glomustumorok mütéti megoldásában jártas fül-orr-gégészek - a túlzott mútéti rizikó miatt inoperábilisnak véleményezték. Palliatív céllal így a vérzékeny daganat legkritikusabb, intracranialis részének szuperszelektív embolisatióját végeztük polivinil-alkohol (PVA-) szemcsékkel. Ennek hatására a daganat vérellátása jelentős mértékben csökkent, a beteg panaszai mér- 


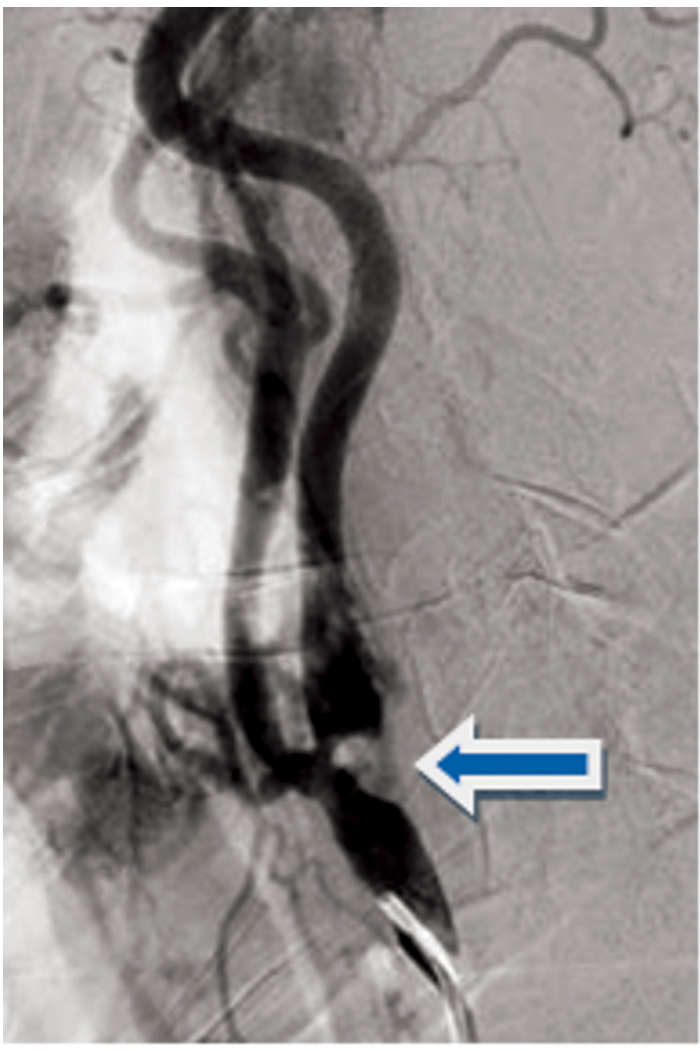

\begin{tabular}{l|l} 
l. ábra & Bal ACI 80\%-os szúkülete
\end{tabular}

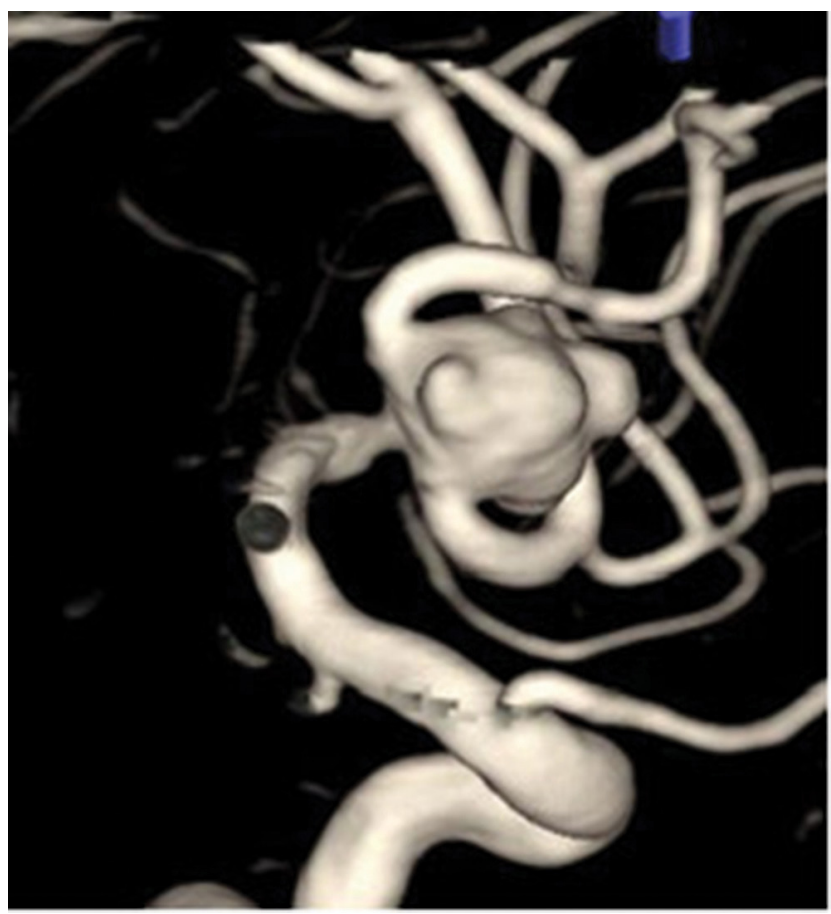

2. ábra

Bal ACM-aneurysma

séklődtek, rekedtsége, nyelése javult ( 8 . ábra). Ezt stereotaxiás sugársebészeti beavatkozás követte. Betegünk klinikai és radiológiai állapota a beavatkozások óta eltelt egy évben stabilizálódott, nem progrediált.

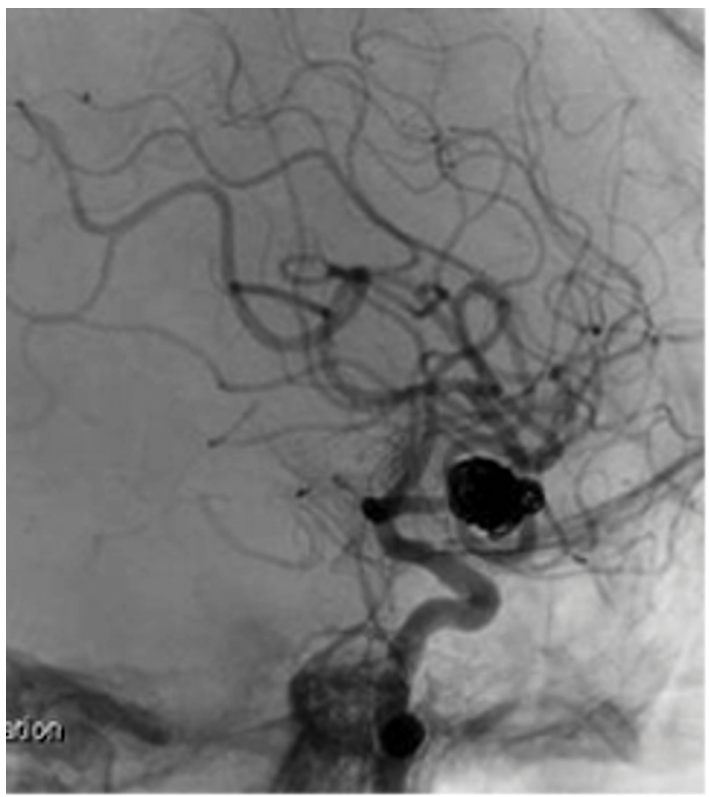

3. ábra | Bal ACM-aneurysma coilozás után

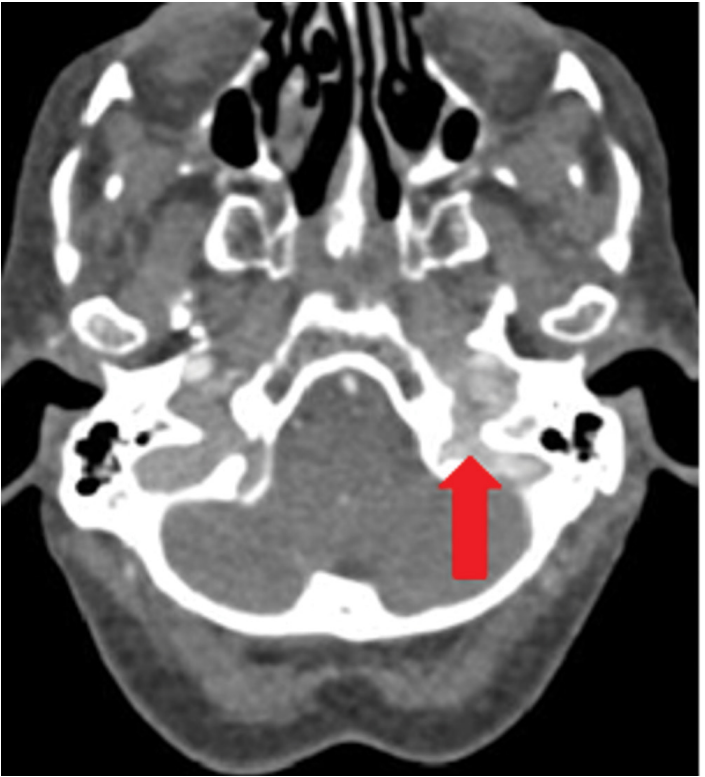

4. ábra

| Kontrasztos koponya-CT - glomus jugulare tumor

\section{Megbeszélés}

\section{Paragangliomák}

A glomusok vagy paraganglionok fontos szerepet játszanak a homeosztázis fenntartásában, stressz hatására kemoreceptorok aktiválódása következik be, amelynek hatására katecholaminokat választanak ki. Ezen speciális ganglionok daganata, a paraganglioma vagy más néven chemodectoma ritka entitás, incidenciája: $0,7 / 1$ millió lakos/év [1]. Lokalizáció alapján megkülönböztetünk glomus jugulare, glomus vagale és glomus caroticum, glomus tympanicum tumorokat. A nagyon jó vérellátású 


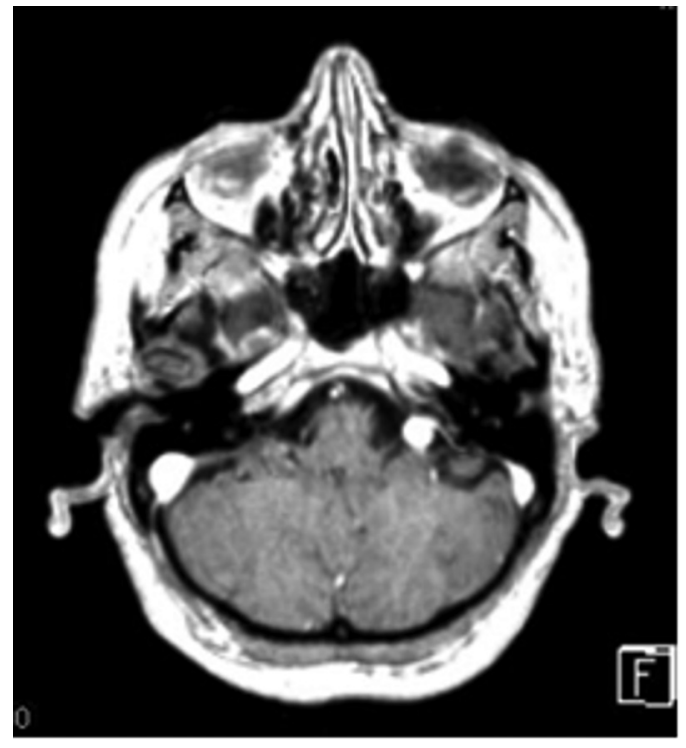

5. ábra | Kontrasztos koponya-MR - glomustumor intracranialis része

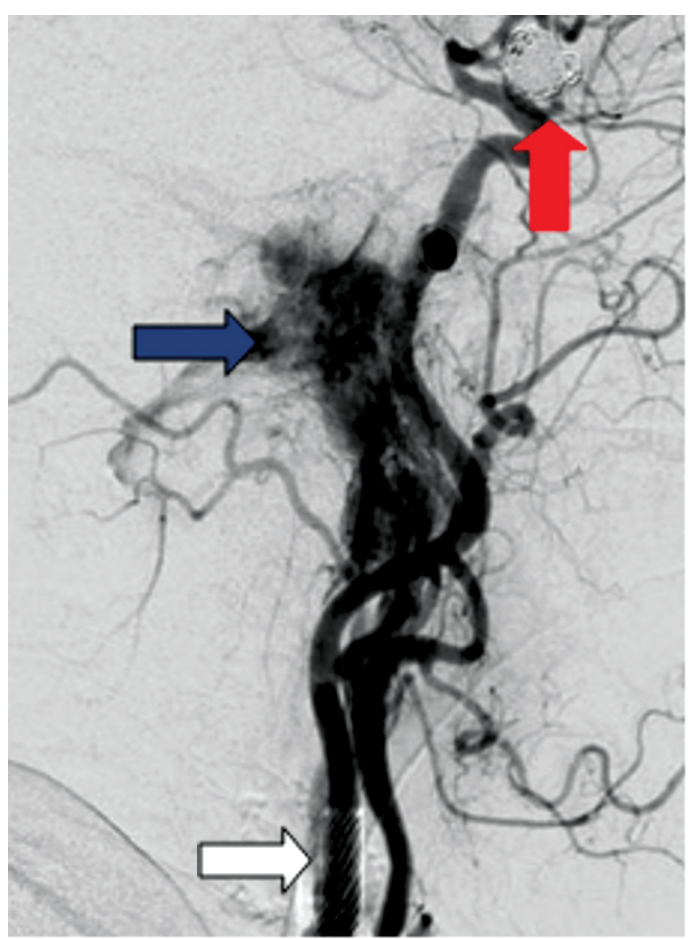

6. ábra

DSA-kép, fehér nyíl - carotis stent; kék nyíl - glomus jugulare tumor; piros nyíl - ACM-aneurysma coilokkal kitöltve

daganatok általában benignusak, általában lassan nőnek. Csak 10\%-uk mutat malignus transzformációt, és ez is inkább a vagus melletti paragangliomákra jellemző. A daganatok megjelenhetnek sporadikusan (10-20\%) és familiáris halmozott formában $(80-90 \%)$ is $[1,2]$. Számos genetikai mutációról igazolták, hogy a paraganglioma rizikóját növeli (SDHAF2, MAX, TMEM127, EGLN1, HIF2A, KIF1B, SDHA) [1]. A sporadikus paragangliomák nőkben gyakrabban fordulnak elő, panaszokat általában a 40-70-es években okoznak. A familiá-

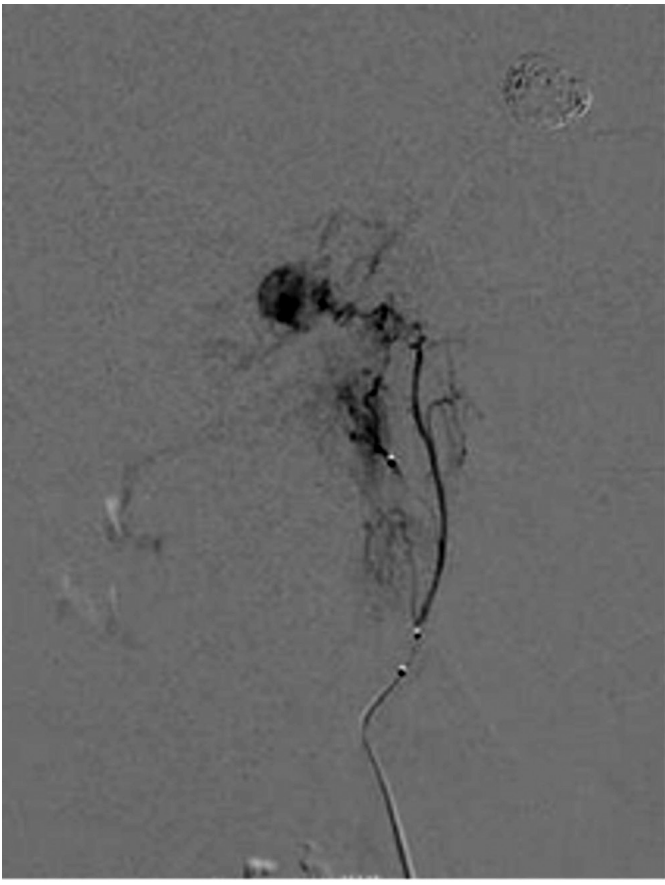

7. ábra | DSA-kép, tumorszelektív embolisatio

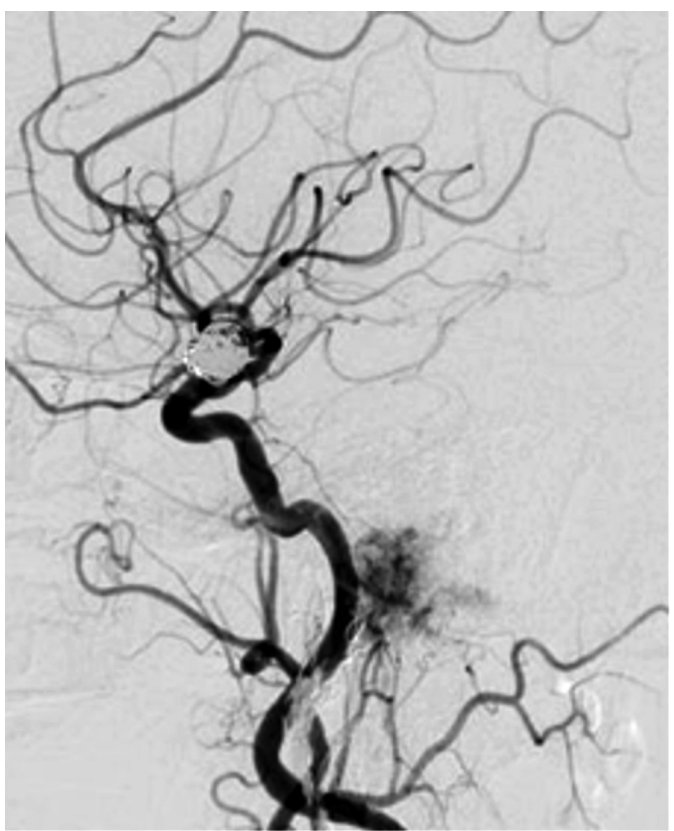

8. ábra

ris forma fiatal férfiakban gyakoribb és gyakran jár együtt I-es típusú neurofibromatosissal, Hippel-Lindau-szindrómával és MEN-II (2-es típusú multiplex endokrin neoplasia) betegséggel [1]. A paragangliomák 3-4\%-a termel vazoaktív peptideket, katecholaminokat. Leggyakrabban norepinefrint, ritkábban epinefrint és dopamint. Ezek hirtelen vérnyomáskiugrásokat okozhatnak, amelyek általában fejfájással, verejtékezéssel és szívtáji palpitációérzéssel járnak együtt [2]. A paragangliomák endokrinológiai aktivitása legbiztonságosabban a plaz- 
ma-szabadmetanefrinek vagy a vizelet-frakcionáltmetanefrinek kimutatásával igazolhatóak. Az aktív paragangliomák katéteres embolisatiója vagy mútéte hirtelen katecholaminfelszabadulást okozhat, ami hypertoniás krízishez vezethet. Emiatt nagyon fontos a paragangliomák endokrinológiai kivizsgálása, a gondos preoperatív előkészítés és a speciális altatási stratégia (alfa-adrenergblokád, hydromorphon alkalmazása, míg a béta-blokkolók, morfin, emerol, atropin, droperidol szigorú kerülése) $[2]$.

\section{Glomus jugulare tumor}

A tympanojugularis glomustumor a középfül leggyakoribb daganata és a második leggyakoribb, temporalis csonton belüli daganat. Leggyakoribb tünete a pulzáló fülzúgás és halláscsökkenés. A glomus jugulare tumor növekedési irányától függően trigeminus neuralgiát, facialis paresist vagy IX-XII. agyidegtüneteket (rekedt hang, nyelészavar, azonos oldali vállgyengeség és nyelvdeviáció) okozhat. Differenciáldiagnosztikai szempontból számos betegség jön szóba, amelyek klinikai és radiológiai megjelenése hasonló lehet: chordoma, eosinofil granuloma, meningeoma, neurinoma, chondrosarcoma, metastasis, cholesteatoma, otosclerosis, krónikus mastoiditis, cholesterolgranuloma, aneurysma, prominens jugularis bulbus, perzisztáló stapedialis artéria, lymphoma [3]. Kivizsgálásában a CT-nek, MR-nek és angiográfiás vizsgálatnak van nagy jelenősége. CT-képen a temporalis csont „molyrágásszerü” képe, MR-képeken „salt and pepper" megjelenés, angiográfiás képeken a hypervascularisatio jellemző rá. A kiterjedés alapján GlasscockJackson és Fisch osztályozta e daganatokat [3]. Fisch felosztása A-D kategóriáig számos alcsoportot alkalmaz, amely figyelembe veszi a daganat nagyságát és a környező anatómiai képletekhez való viszonyát (1. táblázat).

A daganat nagyon érdús, ezért szelektív embolisatio mindenképp szükséges egy esetleges mútét előtt $[3,4]$. Embolisatio után a daganatot kisebb vérveszteséggel, alacsonyabb rizikóval lehet operálni. A leghatékonyabb kezelési módszer egy preoperatív tumorembolisatiót követően a daganat teljes eltávolítása. A Fisch D nagyságú daganatok mütéte azonban nagyon magas mortalitással jár. Inoperábilis esetekben az embolisatióval a tumor vérellátásának csökkenése, teoretikusan a tumor növekedésének mérséklése érhető el [3-5].

Egy glomusdaganat embolisatiója - elhelyezkedésétől függően - megvalósulhat szelektív artériás módon vagy direkt punkció során [5-7]. A glomustumor vérellátását általában az azonos oldali arteria carotis externa ágaiból, azon belül is az arteria pharyngea ascendensből kapja dominálóan. Néha a glomustumorok a carotis interna felől vagy vertebralis irányból, esetleg a contralateralis carotis externa és interna ágakból is kaphatnak afferenseket $[3,6]$. A szelektív transarterialis embolisatio során alkalmazhatunk polivinil-alkohol szemcséket (PVA), etilén-vinil-alkoholt (Onyx) vagy $\mathrm{N}$-butil-cianoakrilát
1. táblázat | Fisch-klasszifikáció

\begin{tabular}{|c|c|}
\hline Típus A & $\begin{array}{l}\text { Tumorinvázió a középfül régiójára lokalizálódóan } \\
\text { (glomus tympanicum) }\end{array}$ \\
\hline Típus B & $\begin{array}{l}\text { Tumorinvázió a tympanomastoid régióra } \\
\text { lokalizálódóan }\end{array}$ \\
\hline Típus C & $\begin{array}{l}\text { Tumorinvázió a temporalis csont infralabyrinth } \\
\text { régiójára lokalizálódóan }\end{array}$ \\
\hline $\mathrm{C}_{1}$ & Tumorinvázió a canalis caroticum vertikális részéig \\
\hline $\mathrm{C}_{2}$ & Tumorinvázió a canalis caroticum vertikális részében \\
\hline $\mathrm{C}_{3}$ & $\begin{array}{l}\text { Tumorinvázió a canalis caroticum horizontális részében } \\
\text { is, foramen lacerum intact }\end{array}$ \\
\hline $\mathrm{C}_{4}$ & $\begin{array}{l}\text { Tumorinvázió a foramen lacerum és sinus cavernosus } \\
\text { érintésével }\end{array}$ \\
\hline Típus D & Tumorinvázió intracranialisan \\
\hline $\mathrm{D}_{\mathrm{el}}$ & Intracranialis, extraduralis terjedés kisebb, mint $20 \mathrm{~mm}$ \\
\hline $\mathrm{D}_{\mathrm{e} 2}$ & $\begin{array}{l}\text { Intracranialis, extraduralis terjedés nagyobb, mint } 20 \\
\mathrm{~mm}\end{array}$ \\
\hline $\mathrm{D}_{\mathrm{il}}$ & Intracranialis, intraduralis terjedés kisebb, mint $20 \mathrm{~mm}$ \\
\hline $\mathrm{D}_{\mathrm{i} 2}$ & $\begin{array}{l}\text { Intracranialis, intraduralis terjedés nagyobb, mint } 20 \\
\mathrm{~mm}\end{array}$ \\
\hline $\mathrm{D}_{\mathrm{i} 3}$ & Inoperábilis intracranialis, intraduralis daganat \\
\hline
\end{tabular}

(NBCA) szövetragasztót a tápláló erek elzárására [6,7]. Ezen a területen a carotis interna és externa ágai között számos „veszélyes anastomosis” van, ami miatt a beavatkozást nagy körültekintéssel, altatásban, képzett neurointervenciós szakembernek kell megvalósítani [7]. Emollitio cerebri és agyidegbénulások lehetnek az intervenciós beavatkozás főbb szövőddményei $[6,8]$. Inoperábilis esetekben potenciális kezelési lehetőség a stereotaxiás sugársebészeti kezelés, amellyel általában jó növekedési kontroll érhetô el $[9,10]$.

\section{Carotisszüküilet endovascularis kezelése}

Ha az arteria carotis interna szúkülete meghaladja a 80\%-ot, akkor - emboliaprevenciós céllal - érsebészeti beavatkozást, úgynevezett carotisendarterectomiát (CEA) vagy neurointervenciós kezelést, angioplasticát és stentelést (CAS) javasolt végezni $[11,12]$. A CEA és a CAS rövid és hosszú távú szövődményrátája megegyezik $[13,14]$. Az endovascularis ellátás indokolt, ha a betegek nem altathatóak, súlyos szív- vagy tüdőbetegek, ha az ellenoldali carotisuk elzáródott, illetve, ha sugárkezelés következtében alakult ki az érszúkület. Ugyancsak CAS-indikációt jelent, ha korábban operálták a carotis internát, ha úgynevezett tandem stenosis, vagyis többszörös carotisszúkület áll fenn, vagy ha a carotisszúkület a sebész számára nagyon magasan vagy mélyen helyezkedik el. 


\section{Intracranialis aneurysma endovascularis kezelése}

Az agyi érzsákok gold standard kezelése az endovascularis ellátás [15-17]. E katéteres ellátás coilozással (mikrospiráloknak az aneurysmazsákba való behelyezésével), széles nyakú aneurysmák esetén ballon vagy stent védelmében végzett coilozással történik. Komplex, másként nehezen kezelhető (például fusiformis) aneurysmáknál sûrű szövésű, úgynevezett áramlásmódosító stentekkel (flow diverterekkel) vagy az érzsákon belüli áramlást módosító, úgynevezett WEB-eszközzel lehet megszüntetni az érzsák keringését. Bizonyos, ritka esetekben a nyílt idegsebészeti mütéti megoldás, a klippelés a választandó kezelési metódus. Számos tényező befolyásolja a nem vérzett, úgynevezett silent aneurysmák vérzési veszélyét, ezek közül a legfontosabb paraméterek az aneurysma nagysága és elhelyezkedése, a beteg magas vérnyomása, dohányzó volta.

\section{Következtetés}

A glomus jugulare daganat ritka kórforma. Gyors progressziója és azonos oldali egyéb érelváltozásokkal járó formája irodalmi ritkaság. A nemzetközi szakirodalomban esetismertetésünk az első közlemény, amelyben a glomus jugulare tumor azonos oldali arteria carotis interna szúkülettel és azonos oldali arteria cerebri media aneurysmával jelentkezett együtt. Komplex, többlépcsős endovascularis ellátásunkkal, illetve az ezt követő sugársebészeti beavatkozással stabilizálni tudtuk a beteg állapotát, ső́t szubjektív panaszai javultak is. Az arteria carotis interna szúkülete a stroke veszélye mellett teoretikusan a dominálóvá váló carotis externán keresztül a glomustumor érellátásának fokozódását, endokrin aktivitásának növekedését okozhatta. Ez pedig az agyi aneurysma növekedését, illetve ruptura veszélyét rejtette magában. A már jelentős nagyságot elért, szabálytalan alakú aneurysma rupturaesélyét magas rizikójúnak tartottuk, ezért ennek ellátását a daganat kezelése elé vettük. Ahhoz, hogy biztonságosan végezhessük az aneurysmacoilozást, először a carotis interna szúkületét kellett megoldanunk. Ez a gondolatmenet határozta meg a kezelési algoritmusunkat. Mindhárom endovascularis beavatkozásunk szövődménymentes volt, technikailag eredményesen valósult meg és a beteg javuló klinikumát hozta.

Anyagi támogatás: A kutatómunka anyagi támogatásban nem részesült.

Szerzői munkamegosztás: Az esetismertetésben szereplő beteg ellátásában és a közlemény megírásában mind a három szerző aktívan részt vett. A cikk végleges változatát mindegyik szerző elolvasta és jóváhagyta.

Érdekeltségek: A szerzőknek nincsenek érdekeltségeik.

\section{Irodalom}

[1] Woolen, S., Gemmete, J. J.: Paragangliomas of the head and neck. Neuroimaging Clin. Am., 2016, 26(2), 259-278.

[2] Colen, T. Y., Mibm, F. G., Mason, T. P., et al.: Catecholamine-secreting paragangliomas: recent progress in diagnosis and perioperative management. Skull Base, 2009, 19(6), 377-385.

[3] Gjuric, M., Gleeson, M.: Consensus statement and guidelines on the management of paragangliomas of the head and neck. Skull Base, 2009, 19(1), 109-116.

[4] Semaan, M. T., Megerian, C. A.: Current assessment and management of glomus tumors. Curr. Opin. Otolaryngol. Head Neck Surg., 2008, 16(5), 420-426.

[5] Liu, J. F., Ni, D. F., Gao, Z. Q., et al.: Diagnosis and therapy of glomus tympanicum and glomus jugulare tumors. Zhonghua Er Bi Yan Hou Ke Za Zhi, 2004, 39(9), 543-545.

[6] White, J. B., Link, M. J., Cloft, H. J., et al.: Endovascular embolization of paragangliomas: A safe adjuvant to treatment. J. Vasc. Interv. Neurol., 2008, 1(2), 37-41.

[7] Abud, D. G., Mounayer, C., Benndorf, G., et al.: Intratumoral injection of cyanoacrylate glue in head and neck paragangliomas. AJNR Am. J. Neuroradiol., 2004, 25(9), 1457-462.

[8] Gaynor, B. G., Elhammady, M. S., Jethanamest, D., et al.: Incidence of cranial nerve palsy after preoperative embolization of glomus jugulare tumors using Onyx. J. Neurosurg., 2014, 120(2), 377-381.

[9] Gottfried, O. N., Liu, J. K., Couldwell, W. T.: Comparison of radiosurgery and conventional surgery for the treatment of glomus jugulare tumors. Neurosurg. Focus, 2004, 17(2), E4.

[10] Pollock, B. E.: Stereotactic radiosurgery in patients with glomus jugulare tumors. Neurosurg. Focus, 2004, $17(2)$, E10.

[11] Brown, M. M., Rogers, J., Blond, J. M.: Endovascular versus surgical treatment in patients with carotid stenosis in the carotid and vertebral artery transluminal angioplasty study (CAVATAS): a randomised trial. Lancet, 2001, 357(9270), 1729-1737.

[12] Kastrup, A., Gröschel, K., Schulz, J. B., et al.: Clinical predictors of transient ischemic attack, stroke, or death within 30 days of carotid angioplasty and stenting. Stroke, 2005, 36(4), 787-791.

[13] Rosenfield, K., Matsumura, J. S., Chaturvedi, S., et al., for the ACT I Investigators: Randomized trial of stent versus surgery for asymptomatic carotid stenosis. N. Engl. J. Med., 2016, 374(11), 1011-1020.

[14] Brott, T. G., Howard, G., Roubin, G. S., et al., for the CREST Investigators: Long-term results of stenting versus endarterectomy for carotid-artery stenosis. N. Engl. J. Med., 2016, 374(11), 1021-1031.

[15] Molyneux, A., Kerr, R., Stratton, I., et al.: International Subarachnoid Aneurysm Trial (ISAT) of neurosurgical clipping versus endovascular coiling in 2143 patients with ruptured intracranial aneurysms: a randomised trial. Lancet, 2002, 360(9342), 1267-1274.

[16] The UCAS Japan Investigators: The natural course of unruptured cerebral aneurysms in a Japanese cohort. N. Engl. J. Med., 2012, 366(26), 2474-2482.

[17] Szikora, I., Marosfói, M., Berentei, Zs., et al.: Interventional neuroradiology: current options. [Az intervenciós neuroradiológia korszerű lehetőségei.] Orv. Hetil., 2015, 156(17), 680-686. [Hungarian] 